the detailed stratigraphy of the sections at the four points of excavation. These excavations were extensive and thorough, but their very complexity makes these chapters difficult to read with comprehension: they are essentially for reference. In these chapters, as elsewhere in the work, occasional misconceptions show up, such as the repeated reference to wood becoming "carbonized by natural ageing processes".

The later volumes will depend on the framework given here, and wo shall await them eagerly, especially that part of volume three in which we are promised an assessment of the site in relation to the general prehistory of Africa. Meanwhile we must be grateful to Clark and his co-workers for this valuable account of the setting for the archaeological feast which is to come.

The book is well produced, with some good illustrations, and is liberally provided with excellent diagrams. By the nature of the sections some of these diagrams are very elongated and have been produced as multi-fold pull-outs. They will inevitably come to grief in library copies, but it is difficult to suggest an alternative form of presentation.

G. W. Dimbleby

\section{VALLEYS IN DETAIL}

\section{The Mediterranean Valleys}

Geological Changes in Historical Times. By Claudio Vita-Finzi. Pp. ix +140 . (Cambridge University Press: May 1969.) $80 s ; \$ 13$.

THIs is an attempt to discover how far Mediterranean streams have modified their valleys during the past 2,000 vears and to demonstrate that these modifications have altered "the main possibilities of human livelihood" within historical times. Obviously, in a land with a strong summer drought, the close connexion between river valleys and settlements, agriculture and routes enhances the significance of changes in valley morphology. Valleys are integral units of a drainage basin, however, and highland slope and lowland flood plain are as inseparable dynamically as are mountains and Marathon poetically. Dr Vita-Finzi investigates valley-fill in detail, but wisely keeps an eye on the watersheds. In this respect, he is helped by the extraordinary smallness of most of the drainage basins around the Mediterranean Sea.

He assumes that alluvial deposits and former erosion surfaces can be dated approximately from their artefact content and "archaeological horizons" and uses these, together with radiocarbon datings, to produce a chronclogy of the geomorphological changes that have occurred recently in stream valleys of an essentially Moditerranean nature. Fortunately, the difficulty or disadvantage of using redeposited objects as chronological tools is offset by the great abundance of artefacts and the existence of several large excavated historical sites.

The first part of the volume presents field evidence from Libya, Tunisia, Moroceo, Algeria, Spain, Italy, Grecec and Jordan. Fach arcal investigation is nicely illustrated with locational maps and cross-sections, long-profiles and the like, of valley-fill. These diagrams have a clarity that does much credit to the cartographic department responsible for them. The roader is further assisted by a collection of forty-three clear photographs.

The general conclusions may be summarized from the field work in northern Tripolitania, where the following chronology was established.

(I) During the last main glacial phase, large quantities of debris (older fill) were deposited in the valleys. This devcloped in parts strong subsurface erusts of lime or calcrete. (2) During post-Neolithic and pre-Roman times the streams cut into this fill, often down to and locally through the uppermost crust. (3) The Romans built numerous dams, largely to hold up silt and lessen floods, but stream-bed crosion continued. (4) At some stage during the Middle Ages, erosion was replaced by aggradation which formed a younger fill up to 10 metres thick. (5) Subsequently, renewed stream downcutting incised channels into the younger fill, leaving it upstanding as a lower terrace above the present streams and floodplains.

From a human viewpoint, the most important of these phases was the mediaeval aggradation which built up much of the richer agricultural riverine lowland in Mediterranean countries and greatly extended the coastal plains and deltas. It buried to a depth of several metres sites such as Banasa on the Sebou in Morocco and Olympia on the Alfios in the Peloponnese.

The factors that may have contributed to the changes in valley morphology are discussed by the author in part two. The older fill is attributed tentatively to climatic change. Since its deposition man has had a steadily increasing influence on the natural landscape. The large-scale deforestation by, for example, the Romans and Arabs seriously affected soil erosion and run-off. The problem, however, as Vita-Finzi sees it, is to disentangle the human influence from more natural causes such as climatic fluctuations. He favours a climatic factor because aggradation occurs over such a wide area of the Mediterranean lands and because mediaeval Europe experienced a "minor Ice Age". "Little more than this can be said until a better understanding of the relationship between modern hydrological regimes and stream geometry makes it possible to interpret past stream morphology in terms of discharges, regimes and ultimately climate" (page 115).

It happens that Dr Stanley Schumm has continued the work on these lines already noticed by the author in his long bibliography. Schumm, in "Geomorphic Implications of Climatic Changes" (Water, Earth and Man, edit. by R. J. Chorley, Methuen, 1969), is mainly" concerned with stream geometry. In it, he elaborates the idea that at a temperature of about $10^{\circ} \mathrm{C}$ sediment yield from a drainage basin increases with rainfall up to about $470 \mathrm{~mm}$ of precipitation and then begins to decrease. Irrespective of the exactness of the suggested optimum (which would vary with temperature), it, seems that the drier parts of the Mediterranean lands are in a transition zone where slight changes in precipitation could cause appreciable changes in run-off/sediment yicld relationships. Thus a problem remains. Is climatic change also "a necessary precondition for historical aggradation"? Or equally, to quote again from Harris and Vita-Finzi in their recent article on "Kokkinopolis-a Greek Badland" (Geog. J., 134, 537; 1968), is the present gullying of Mediterranean valley-fills "a locally intensified manifestation of a general, climatically-induced erosional phase"?

Thus The Mediterranean Valleys presents a subject that will interest a wide range of rcaders, including historians, geographers, archaeologists and, it is hoped, soil conservationists everywhere. The author sets out his field evidence in a scholarly way and cleverly exposes the fascinating complications of an unsolved problem that hitherto has all too often been clobbered by dogmatic assertions. Rorert P. Beckinsale

\section{STRUCTURE OF LIFE}

\section{An Introduction to the Structure of Biological Molecules}

By J. M. Barry and E. M. Barry. (Prentice-Hall Biological Science Series.) Pp. ix +190 . (Prentice-Hall: Englewood Cliffs, N.J., and Hemel Hempstead, 1969.) $50 s$.

THE most dramatic transformation in biological thought since the announcement of the Darwinian evolutionary 